Klein, W. (1982). Local Deixis in Route Directions. In R.J. Jarvella \& W. Klein (Eds.), Speech, Place, and Action: Studies in Deixis and Related Topics (pp. 161-182). New York: Wiley. 
Speech, Place, and Action

Edited by R. J. Jarvella and W. Klein

(C) 1982 John Wiley \& Sons, Ltd.

\title{
Local Deixis in Route Directions ${ }^{1}$
}

\author{
WOLFGANG KLEIN
}

'Here comes the night'

(Van Morrison)

This study deals with the semantics of local deictics like 'here', 'there', 'left', 'right', etc., i.e. with expressions that are used mainly to refer to localities and whose reference depends in a systematic way on contextual factors like position of speaker, direction of gaze, and others. It is part of a larger project on the role of verbal and situational context in language behaviour (cf. Klein \& Levelt. 1978). There are numerous contributions to a theory of context dependency (see. for example, Kratzer \& von Stechow, 1976), and there are some instructive studies of local deixis in particular (e.g. Bühler, 1934; Fillmore, 1971; Atkinson \& Griffiths. 1973; Miller \& Johnson-Laird, 1976, Chap. 6.1; Clark 1977). but it is surely no overstatement to say that we are still far from an understanding how deixis - and local deixis in particular-really works in actual communication. It is obvious that what 'here' means in an utterance is largely determined by the context of that utterance. Sentences like 'Here are the tigers' or 'Come here!' seem to have an open slot, that is filled by contextual information when they are uttered; this contextual information may be given by prior verbal expressions, by succeeding verbal expressions, by common perception in the speech situation, by gestures, etc. Not very much is known about this process, about its components and how they interact. In this paper. I try to contribute to an understanding of this mechanism in two ways-one more theoretical, the other more empirical. In the first section, several problems are outlined which, in my view, are basic to the use of deictic expressions and of local deictics in particular. In Section 2, some results from an empirical study about the use of local deictics in route directions are reported. The first part makes no claim to be a theory of deixis; rather, it forms a heuristic frame of analysis, and perhaps a starting point for such a theory. 


\section{COMPONENTS IN THE USE OF LOCAL DEICTICS}

The following considerations focus upon 'here' and 'there'; but it should be clear that there are a number of other local deictics which are not dealt with here. A speaker who uses expressions like 'here', etc., in some speech situation refers to certain denotata. By saying 'It's pretty cold here', he may refer by 'here' to a room, to a corner of a room or to Siberia, depending on the particular context. A listener who wants to understand this utterance has to identify the specifically intended denotatum of 'here', just as he has to identify the denotata of proper names, of adjectives, or of verbs. But the identification problem is different in at least one respect: 'Siberia' in general denotes Siberia, but 'here' doesn't denote here. Solving the identification problem in deictic reference involves the solution of a whole series of sub-problems and at least the following ones: a common deictic space must be set up; a basic reference point ('origo') must be set up; speaker and listener must coordinate their perspectives; what 'here' and 'there' refer to must be delimited; the deictical oppositions of the language must be utilized; analogical deictic spaces must be established. The comments I shall make now on these problems treat them mainly as research problems, not as problems a speaker and listener have to solve together, though this is exactly what they do have to do in order to achieve successful communication.

\subsection{Setting up deictical spaces}

In general, the possible denotata of local deictics are localities, such as rooms, apartments, streets, cities, countries: they can be considered as subspaces of deictic spaces, such as the space of visual perception, or the space constituted by our geographical knowledge. But the denotata of local deictics need not be localities. When somebody says, 'Two problems should be kept apart here', he surely doesn't refer to a locality in the literal sense of the word, but to a very abstract 'place' in a train of thoughts. And if we read, 'In 1806, Shelley wrote his "Elegy"; here, the spirit of English romanticism found its. . . '. no locality is denoted, unless the denotatum of 'in this poem' is regarded as such. Uses of that type might be called 'metaphorical'; this is perhaps accurate, but it doesn't say very much: it is just a terminological immunization of the problem. What we have to account for is the fact that there may be very different deictic spaces; some of these uses may be primary in a diachronic or in an ontogenetic sense; others might be derived from the primary ones; but this doesn't obviate the fact that they all are at the disposal of a normal speaker, and that, in a specific communication situation, it should be clear which deictic space is being referred to. For instance, is it the space of visual perception, as in 'Here is my home', or the space that is constituted in our memory by our geographical knowledge, as in long-distance calls, when 
somebody says 'It's raining here', or even a much more abstract space, as in 'I can't go into detail here'? The deictic space of speakers and listeners need not be identical for a successful communication, but they must be sufficiently similar, and to make them so might well be a part of the communication; this is the case, for example, in route directions.

In its most general sense, a deictic space is nothing but a set of elements provided with some structure (an order or a topology); its subsets, or some of them, arc the possible denotata. Deictic spaces may differ in (a) what is considered to be their elements, such as minimally discriminable units of perception, words (as in the Shelley example?), etc.; (b) subsets which are possible denotata, such as visual objects, poems, etc.; (c) kind of structure characterizing the deictic space; (d) number of dimensions: the space of visual perception is generally thought to be three-dimensional, a map that often serves as an analogical deictic space (cf. Section 1.7 below) is twodimensional, a 'train of thought' might be considered as one-dimensional (it often is!), etc.; (e) kind of metric - if there is any: for most deictic spaces, we seem to have a concept of distance, but it is often doubtful whether it really fulfils the criteria of a metric. The concept of deictic space raises a number of problems for empirical research:

What then, are the deictic spaces used in actual communication, since the notions 'space of visual perception', 'geographical space', 'space of trains of thought', are somewhat fuzzy labels generated from specific examples? How do speaker and listener make sure that they are referring to the same, or a sufficiently similar, deictic space in a given situation? How are these different concepts of space interrelated, and. in particular, which structural properties are conserved in the transition from basic deictic spaces (visual perception, for instance) to more abstract ones?

Agreement upon the deictic space by speaker and listener is the first prerequisite for successful deictic reference: the intended subspace-locality or whatever-is now to be localized within this deictic space. This is done by a series of techniques, the first of which is to fix the basic reference point.

\subsection{Fixing the bask reference point}

Given a deictic space, one of its elements must be fixed as the basic reference point, in relation to which the denotata can be determined. In the unmarked case, this 'origo' (a term used by Bühler, 1934) is given by the position of the speaker: every participant of a speech situation brings his perspective with him. and it is that of the speaker that is crucial for the identification of denotata: 'here' denotes a space around the origo: 'there' denotes a space that does not contain the origo. This presupposes of course that the speaker (or his body, or perhaps his eyes) can be interpreted as an element of the deictic space in question, as, for example, in the space of visual perception. If this is 
not the case, some reference unit must be set up in the corresponding deictic space. This is often done in anaphorical uses of 'here', as in sentences like 'The reader is referred to Morton (1976); here, the problem of recursive reference is treated in full detail'. ${ }^{3}$ On the other hand, an origo given by the speaker may be shifted. This is often done by pointing gestures: 'The picture here originally hung there' (pointing with a finger to some place), or in the case of analogical deixis (cf. Section 1.7 below): 'If the church is here' (pointing to some spot on the table), 'our home is just here' (pointing to another spot). The origo proper is not lost, it is just suspended in favour of another 'secondary origo", and it is always possible to go back to it without making this explicit.

Fixing the origo raises again a number of empirical problems. How is the (primary) origo precisely characterized-is it the speaker's body, his trunk, his eyes, his reach? How are secondary origins introduced, e.g. by pointing gestures with fingers, chin, eyes, by verbal means? How do children acquire the technique of origo shift?

Explicit origo shifting should not be confused with change of origo due to the speaker changing location during his utterance. If somebody moves through a room saying: 'From here, it's precisely one, two, three, four, five metres to here', the denotatum of 'here' changes within one speech act, and the origo is shifted, too, within that speech act. But it is still the basic type of origo implicitly given by the speaker's position. This constitutes a clear argument against the assumption that the origo is bound to the speech act. This seems to be the position held in Wunderlich (1971). If a speech act (or the speech situation that exactly corresponds to a speech act) is restricted to utterances of just one speaker whose position is unchanged, it doesn't matter, because both assumptions (origo bound to speech act; origo bound to position of speaker) coincide. But as soon as examples where this is not the case are taken into consideration, it becomes apparent that the speaker's position is crucial. Moreover, this view can easily be linked to the extended research on children's egocentrism and to adults' orientation: we learn to shift, but basically, we see. grasp, feel, structure, our surroundings from where we are.

\subsection{Co-ordination}

In the following. I shall only consider unmarked cases, i.e. cases where the origo is implicitly given by the speaker's (stable) position. The listener must take over this orientation; he must project it onto his own system of orientation, which is not at issue as long as he is listening. As soon as he starts speaking, roles are changed, and his orientation becomes central; the projection task becomes his. In many cases, the problem of co-ordinating two systems of orientation is trivial. The denotatum of 'here' often encloses both 
speaker and listener, and any difference in their position and hence in their orientation is irrelevant-though it exists. But there are many cases where the different position becomes important. A particularly clear example is telephone calls: 'The weather is wonderful here'-'Oh, here it's raining'. Of course this is not restricted to telephone calls, but also happens in face-to-face interaction. If somebody outside a house is speaking to somebody leaning out of the window, he may say 'It's cool here', and the other speaker may respond: 'Oh. you should feel it in here!' In cases like this, the denotatum of 'here' centres so narrowly around the respective origo that it doesn't include the position of the respective listener. This point becomes move obvious, if not only the position of the speaker, but also his direction of gaze is important, as with the local deictics 'left' and 'right'. If speaker and listener are facing each other, one's 'left' is the other's 'right'. In this case, the co-ordination is very simple; ${ }^{4}$ it is more complicated if there is an angle of $90^{\circ}$ between the two directions of gaze, because then, the speaker's 'left' is the listener's 'right', if the listener is to the speaker's left and the locality referred to is between them; if it is not between them, it is to the left of both listener and speaker. Things are much more unclear with 'here' and 'there', in cases when a non-trivial co-ordination is necessary: the speaker's 'here' is often the listener's 'there', one of the speaker's 'there's is the listener's 'here', the speaker's and the listener's 'here' may overlap without coinciding totally, etc. These mappings are very complex, and they become still more complex if shifted origins are considered. This leads to research problems such as: How do these mappings work in the unmarked case where speakers change position? How do they work in the case of shifted origo?

\subsection{Delimitation}

Fixing the origo of a given deictic space and mapping the two systems of orientation doesn't guarantee that the subspaces-the denotata-can be identified. The denotatum of 'here' is indeed not the origo itself, but some space enclosing the origo. Saying 'it's cold here' means 'it's cold within some area around the speaker', and neither the origo nor the word 'here' indicate how far this area reaches. The boundaries are fixed by the context of the utterance. This delimitation follows certain principles. 'Here' may refer to the chair on which I am sitting, to the room where I am. to the house where I am. to the street, the city. etc.. in widening circles around the speaker which may or may not include the listener. ${ }^{5}$ But it is very unlikely that a particular 'here' will be used to refer to a chair (with speaker) and the surrounding space at an exact distance of $69.3 \mathrm{~cm}$. or to the room and two adjacent rooms-unless they form a cognitive unit in some sense, such as the reach of the speaker, or in the second example, an apartment. In many cases, the delimitation is immediately supported by some verbal means, e.g. 'here in this tiny cabin, he spent half a 
year", or 'here in Heaven, they sing too much'; but this does not have to be the case. We often reconstruct the borders of 'here' (and other local deictics) by our knowledge of the world. If somebody says 'I'm sitting very comfortably here", our general knowledge tells us that 'here' does not refer to the Earth, whereas in 'there is no justice here', it doesn't refer to a chair.

Obviously, the delimitation is not always very sharp; the borders are often diffuse. But fuzziness of denotata is not a specific problem of local deixis. The central empirical problems raised by the necessity of delimitation are: What are the possible borders within a given deictical space (a room might be a denotatum, but not a room and half of the next)? How is the delimitation established in a given speech situation-by verbal context, by components of our factual knowledge, by gestures?

\subsection{Deictical oppositions}

Deictic space, origo, co-ordination, and delimitation make it possible to identify the denotatum of 'here' in a given context-it is a subspace of the deictic space including the origo within certain boundaries. But 'here' is not the only local deictic expression. It belongs to a certain system that, according to the language, may have two ('here'-'there'), three ('hier'-'da'-'dort'. 'aquí'-'allí'allá'). or even more components. And there are. of course, other groupings of deictical expressions, like 'left'-'right' which form their own system. Several proposals have been made to characterize the oppositions of such deictic systems in different languages, such as 'proximal' versus 'nonproximal' for English (e.g. Clark 1977), or 'proximal'-'middle'-'distal' for Bella Coola (Davis \& Saunders. 1975). or the traditional 'near the speaker'-'near the listener'-'near the third one' in Latin grammar for 'hic'-'istic'-'illic'.

But even in the comparatively simple 'here*-'there' system of English, things are sometimes rather complicated, because what 'proximal' and 'nonproximal' mean again depends on the context. It is apparently possible to say 'here comes my mother', when she is at a distance of KM) metres, but one can also say 'there is my mother', when she is at a distance of 10 metres. 'There' can be used if the denotatum is closer to the speaker than to the listener (but 'distant' from both), but it can also be used precisely in the sense of the opposition 'speaker-here' versus 'listener-there' (e.g. 'You can't see it from there, only from here') The system seems to work roughly as follows: in a given situation, a 'here' always denotes a subspace of a deictic space around an origo (shifted or unshifted); the rest of the deictic space is-in that situation-open for possible denotata of 'there": 'there' denotes some subspace of the complement of a 'here'. Precisely what it denotes is then marked by three characteristics: (a) negatively by the respective denotatum of 'here'-if no here' is used in that particular situation, the whole deictic space is open for 
'there', except that it must not include the origo;" (b) by some additional information concerning the location within the space, e.g. some pointing gesture, some verbal expression-as in the case of anaphoric or cataphoric 'there'-by shared perception, etc.; (c) by some additional information concerning the delimination (as in the case of 'here').

If the opposition is understood in this way, the 'proximal'-'non-proximal' distinction is just a special case. The situation is much more complex with three-step systems, as 'hier'-'da'-'dort' in German, where 'da'-apart from its other meanings - competes both with 'here' and 'there': 'Ich bleibe ein paar Minuten da' versus 'das Buch muß irgendwo da (pointing with the finger) gelegan haben'. These systems differ from language to language, and the analysis of their constitutive oppositions is one of the research problems raised by them. The other one is by what means a speaker makes clear in a given speech situation where his 'there' is located and what its borders are (cf. (b) and (c) above).

Basically, we now have all the components that usually interact to determine what is referred to by 'here' or 'there'. This mechanism of deictic reference with shared deictic space, origo fixing, co-ordination, delimitation of subspaces, and deictic oppositions looks rather complex, but I don't see what could be omitted from it. On the contrary, the system becomes even more complicated if we take into account some other everyday uses, namely those that involve analogical deictic spaces.

\subsection{Analogical deixis}

If somebody points to a red spot on a map and says: 'Here is my home', he wants to say 'At the place that in reality corresponds to this spot . . . and he is normally understood that way. In this case, we have two deictic spaces involved: the map. and the geographic space represented by the map. The map functions as an analogue, and by pointing to an element of the map. I am referring to the analogous place in the real space'. The mapping is here (!) clearly given by the given projection. But analogical deixis is also possible when the mapping is not given by some geometrically defined relation, but by some-perhaps vague-resemblance. If somebody points to his own shoulder and says: The bullet hit him here', he refers to the corresponding part of the body of some other person. In the same way. it is possible to refer to 'generic places'. If a professor of medicine says in a lecture: 'The needle must be inserted precisely here', pointing on some part of his own hand, he doesn't actually refer to the part of his hand he is pointing to-he would be astonished if the students all wanted to inject him there-nor to the corresponding part of some other specific person, but to the part of the 'generic hand', of which he used his own as an instance.

The central empirical problem of analogical deixis is the kind of mapping 
between the deictic spaces involved. It is apparently possible to say 'The bullet hit Charlie here' (pointing on one's shoulder), even if Charlie is not a human being, but a grizzly bear; it's impossible, however, if Charlie is a snake.

This seems the right point to close these comments on the mechanism of local deictic reference Perhaps they raise more problems than they clarify, but they may serve as a basic framework for further analysis. In the following, some results concerning the use of deictics in route directions are outlined. Though there will often be no explicit reference to the conception, the whole study should be seen in the context of this framework.

\section{USING LOCAL DEICTICS IN ROUTE DIRECTIONS}

\subsection{Route communications}

In English, there seems to be no standard term for the complex co-operative verbal action that consists of asking for route directions and giving them-as for instance 'Wegauskunft' in German; in the following. I will call this action 'route communication'. It is a very common type of complex verbal action. By complex verbal action. I understand activities like giving a talk, recounting a narrative, explaining a game, describing an apartment, arguing together, etc. In general, several participants - at least two-are engaged in such an action, but their role might be different. According to that. I classify them as basically monological or basically non-monological (giving a talk is basically monological. arguing together is basically non-monological); a complex verbal action might indeed be composed of several passages, some of them being monological. some not. A second subdivision follows the type of information to be presented or elaborated: it may prestructure the verbal planning to a high or a low degree. Narratives are strongly prestructured by the temporal order of events, explaining games weakly structured; that's why most people soon get confused when they try to explain a complex game. In the weakly prestructured case, people typically try to introduce some temporal ordering, e.g. by following the running of the game, by imaging a tour through an apartment (Labov \& Linde. 1975). etc. Route communication shows a clearly asymmetric role of its participants that is reflected in the verbal tasks they have to carry out: the person who asks for directions (henceforth F) wants to know something, and he tries to get this information from somebody he takes to be competent and willing to give it (= A). F's initial tasks are: (a) getting into contact with A: (b) making clear what he wants: (c) succeeding in getting A to take over the task of giving him directions. If he succeeds, it is up to A to make clear to F how to reach his destination: he has the task of (d) describing the way (route directions proper): (e) making sure that $\mathrm{F}$ understands. It is then up to $\mathrm{F}$. who set the task, to take it back and to conclude the interaction. F then has the task of (f) attesting to A that his job is done; (g) acknowledging 
A's help; (h) ending the contact. As a rule, these three groups of tasks correspond to a clear interactional scheme of successful route communication. In the first part ('introduction'), $\mathrm{F}$ is dominant from an interactive point of view: (a)-(c) are carried out. In the second part ('central sequence'), A takes over and becomes dominant: (d) and (e) are solved. In the third part ('conclusion'), F is dominant again: (f)-(h) are carried out. There may be deviations. If $\mathrm{F}$ is successful with (a), but not with (b), everything drops until (h). There may also be overlaps or repetitions, but typically a route communication follows this scheme.

Route communications are interesting from an interactive, a cognitive, and a linguistic point of view. They are all closely linked, of course; but in the following, I shall concentrate on the third aspect, with some remarks on the second one, where necessary; almost nothing will be said about the interactive aspect. Only point (d), the route directions proper, are dealt with here, because it is the most yielding in the present context. (For a more detailed analysis of route communications, see Klein, 1979).

The study is based on 40 route communications in natural context. They were gathered in May 1977 in the inner city of Frankfurt/Main by students (cf. Figure 1). At the upper Zeil (a), the main shopping street, or at the

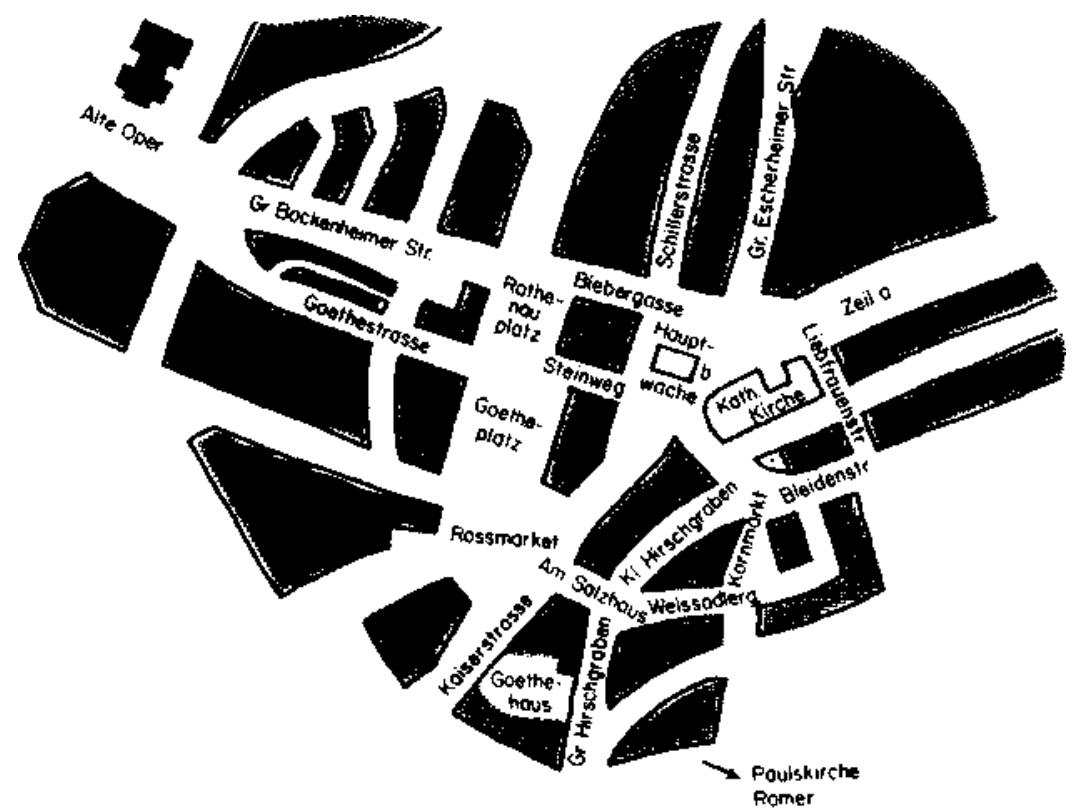

Figure 1 Simplified map of a part of central Frankfurt 
Hauptwache (b) (a small historical building from the early eighteenth century) people were asked either for the 'Alte Oper' or the 'Goethehaus', both well-known landmarks in Frankfurt. The whole action was covertly recorded using a Nagra SNN audio tape recorder. Approximately 100 route communications were recorded, some of them very noisy because of the traffic. The first 20 for each destination (Alte Oper, Goethehaus), if fully understandable, were selected and transcribed for further analysis; they are labelled as 01 - 020 and G1-G20; a selection is given in the appendix. The transcription is in standard orthography, with some slight touches of dialectal pronunciation for some speakers. Pauses and parallel speaking were transcribed as accurately as possible. Sometimes, more than one person answered; in this case, indices are used: $A_{1}, A_{2}$, etc.

\subsection{Planning the description}

In order to describe how to go from the starting point to the destination. A must have some cognitive representation of the area in question. In general, he owes his knowledge to his own previous experiences, e.g. he remembers what he has seen and heard and how he moved, or how the streetcar moved, and this remembrance must be structured into a cognitive map, e.g. he knows that at a certain place there is such and such a building where he can turn left, that he can't cross the steet there, etc. Two people may have different favourite routes, and their attention may be focused on different objects. There are likely to be objects which are salient landmarks for nearly everybody (cf. Lynch. 1960). but whether the image somebody has of an area is marked by book stores or fashion shops will differ between individuals. Thus, cognitive maps may be differently structured to a large extent. Moreover, they can be vague, incomplete, or even wrong in some respects (see, for a recent discussion of this concept. Downs \& Stea, 1973, 1977). This can, but need not be. relevant for route directions.

A's cognitive map is activated, at least to some extent, by F's initial request. What A has to do then is localize the starting point and destination on his map. Such a segment of a cognitive map with starting point and destination localized will be called the 'primary plan' of the route direction. Localizing the destination is sometimes not easy, and it might involve complex strategies (cf. text 03 . G2. or the fantastically complex G1). The starting point in general raises no problems because it is in the domain of visual perception, whereas a great deal of what else is represented in the primary plan-for instance, the destination in most cases-is not in the domain of visual perception; indeed. A sometimes looked or even turned around to find out where he was-to localize his position. Building up the primary plan may be done in 
advance, or step by step. Consider G11:

F Entschuldigung, können Sie mir bitte sagen, wo's zum Goethehaus geht? Fxcuse me. could you tell me how to get to the Goethehaus?

A

F $\quad$ Ja

$$
\text { Yes }
$$

A [3 seconds) Goethehaus? ja, gehen Sc da rauf, immer geradeaus. Goethehaus? yes, go up that way. always straight on.

erste Straße links, erste Straße rechts

first street to the left, first street to the right

F erste links, erste rechts dankeschön.

A

first left, first right thank you

ja

yes

A makes a planning pause after the question: then he reaffirms himself that he has correctly understood the question, indicating that he is able and willing to answer; and then, he carries out his description in one stroke. When speaking, he apparently has a sufficiently clear primary plan; he is an 'advance planner'. His counterpart may be called 'stepwise planner'. A clear example is in G15:

F

A Ja; [10 seconds] hier die Zeil runter, auf der andern Seite, ja Yes; here down the Zeil, on the other side. yes

$\mathrm{F}$

A [ 14 seconds] praktisch gehen Se jetzt hieran [ 13 seconds] eh [3 seconds] in fact you go along here now er

F

A Sie müssen wohl von hinten rüber. weil da ne Ampel ist. ja: you probably have to cross over from there, because lights

$\mathrm{F}$

A

da hinter der Kirche lang; dann gehn Se are there, yah: there along behind the church; there you go

$\mathrm{F}$ 
A rechts die Straße wieder grad runter und dann müssen Se
down that street to the right again and there you have to
F

A bis zur [2 seconds] wie heiß'n das? auf der linken Ecke [4 seconds] go to the what's it called again? The left corner

$\mathrm{F}$

A bis die ne Rolltreppe kommt, da is Möbel Mann, diese Straße till you reach the an escalator, there's Möbel Mann, that street $\mathrm{F}$

A

müssen Sie links rein; und die erste wieder rechts;

you have to go in to the left; and the first one again to the right;

F gut. dankeschön

A

okay. thank you

also, auf der einen Seite ist. eh

well, on the one side, there is. er

A Neckermann. Reisebüro, und auf der andern Straßenecke ist Neckermann. a travel agency, and on the other street corner there is $\mathrm{F}$

A Möbel Mann; die Straße links rein und dann die erste Möbel Mann; that street you go in to the left, and then, it's the first rechts.

right.

Though reflecting at the beginning. A has no clear plan when he starts speaking. He soon comes to a point that is problematic; he then reflects on the situation-he tries to elaborate his primary plan there-restarts at the beginning, arrives again at the point of confusion, reflects again, and then advances a little bit further, until the next unclear position is reached; he tries to picture the situation there to himself, and then is able to continue to the end. After that, he has no difficulty in recapitulating a part of his description; the plan being there, he is able to repeat, vary, or extend his description. He doesn't work out a complete plan in advance, but starts speaking as soon as he has got the first bit ready, and he then goes on step by step. Planning in advance and planning stepwise are complementary techniques, and it is an open question whether the> represent individual styles or whether their use simply depends on the particular task. Having a gap in the conversation-and a long planning 
pause is such a gap-is awkward, and it may well be that A in G15 starts simply because he doesn't like the propsect of a gap.

The primary plan, whether built up in advance or stepwise, is a first condition for a successful description. But less than the whole primary plan is reported, of course; this would contain a lot of information that is superfluous for the purpose of the required route directions. The speaker must select from it and arrange those pieces of information he thinks to be relevant for the listener. He has to form a 'secondary plan' which will immediately underlie the linearized sequence of verbal expressions, with which he describes the route. The organizing principle of this secondary plan is that of an 'imaginary journey' through the primary plan from starting point to destination. During this journey, certain points of the primary plan are selected and marked; this series of 'fixed points' forms the skeleton of his description. His directions have three components: fixed points are introduced, directions relative to the fixed points are marked, and actions (or events) are indicated. Consider the following passage from 04 :

$\mathrm{F} \quad[\ldots]$

ja

yes

A

Ja, [5 seconds] jetzt gehn Sie vor. bis ganz vorn hin Yes.

$\mathrm{F}$ you go on here, until right before

F ja

A bis Sie an den Kaufhof stoßen dann gehen Sie links rein, till you run into the Kaufhof then you go there to the left

$\mathrm{F}$ ja

yes

A dann ganz links, dann kommt erst die Schillerstraße. the Biebergasse well you go on here and then you stick

$\mathrm{F}$

A dann ganz links, dann kommt erst die Schillerstraße.

to the left. then you come first to the Schillerstraße.

$\mathrm{F}$ $\mathrm{mhm}$

$\mathrm{mhm}$

A die überqueren Sie da is vorn an der Ecke is ein

there you cross over there is on the corner there is a

$\mathrm{F}$

A Herrenboutique. da gehn Sie dran vorbei.

men's shop. there you go right past.

The first fixed point after the starting position is the Kaufhof (a big department store); here, the walker has several possibilities, one of which is marked: 
'links rein'. In other cases, possible alternatives are explicitly excluded. This is not done in the present example; here, only the right direction is indicated as such, in fact, given twice: once by the deictic statement 'links rein', and then by the additional information "die Biebcrgasse'; A has incorporated a unit of his primary plan that is not absolutely necessary but which provides additional help. Then, the route is repeated until a new fixed point is reached: Schillerstraße. In this way. point after point is selected, verbally introduced, and this skeleton is completed by commentary or additional information that helps to make sure that $\mathrm{F}$ gets the message. And he has got it if he has succeeded in building up a rudimentary image of the area, one that essentially consists of a series of selected points, and if he knows what he has to do at these points.

This information is given by three types of descriptive expressions ${ }^{7}$ that the speaker uses: expressions that introduce fixed points, deictic expressions that link certain fixed points, and expressions for what $\mathrm{F}$ has to do there or what happens there: in a sequence like: '. . . until you get to a small house with green shutters; there, turn left', a fixed point ('a small house with green shutters') is introduced: the local deictic 'there' refers to that fixed point, or rather to a locality close to that fixed point, and then the listener is told what has to be done at the denotatum of 'there'.

\subsection{Local deixis}

After these general considerations on planning, let me turn to the specific problem of deictic reference in route directions. It is characterized by two specific features:

(1) Speaker and listener do not share a deictic space at the beginning. They share a perceptual space, but this is not enough. The listener at first doesn't have available the deictic space represented by the speaker's cognitive map of the area in question. Hence. A has to provide F with the idea of such a deictic space, or the indispensable elements of it; and this is what is achieved by introducing fixed points and giving additional information.

(2) The origo is given by the location of the speaker which, in this case, doesn't differ crucially from that of the listener. But then, the location of the speaker and listener-of the imaginary walker-is constantly shifted, or rather thought of as shifting during the imaginary walk.

In general, there is no problem of co-ordination: the orientation of $\mathrm{A}$ and $\mathrm{F}$ in the imaginary walk is thought to be identical, and at the starting point, it either differs in a trivial way that doesn't affect the use of deictics or A changes his position or his direction of gaze (or causes $F$ to do so) to this effect. The delimitation is generally based on factual knowledge; it is rarely explicitly specified. The deictic oppositions are as usual, and analogical deixis 
is rarely used. In the following, I shall concentrate on the two points mentioned above: building up a rudimentary deictic space that mainly consists of a series of fixed points, and the moving origo and its function for the identification of denotata. The fixed points used are streets, places, buildings, etc. There are essentially four ways for a listener to recognize what the speaker intended as a fixed point:

(1) On the basis of his previous knowledge, the speaker expects that the listener simply will know some landmarks, or he can check this by questions like: 'Do you know where . . . is?'-'Yes'-'Okay, there it's . . .'.

(2) On the basis of visual introduction, mainly by pointing gestures, e.g. in G17. where A says: 'Sehen Sic dieses Schild Bill-Binding da oben ja?'-F: 'Ja, ja'-A: 'Okay, und dann da geradeaus'. This is only possible for the space of visual perception, of course.

(3) On the basis of (non-deictic) descriptions, such as in G6: 'bis Sie an den Platz kommen, wo eh son'n großes Brunnen rausspringt, da gehn Se links runter', or G16: 'Um wenn Se e Stück drin sin, wo die Leute da sitze, dann

(4) On the basis of indications relative to a previous fixed point; this is often done with expressions like 'the first . . . after', 'the next. . . . etc., e.g. in G16: 'da gleich bis zur nächste Ampel'. This strategy is very frequent, and some speakers, as A in G11. use it exclusively: the first reference point is that starting point, and all other indications of fixed points are related to this first one.

Typically, these possibilities are used in combination with each other. In the following, one example (from G10) is considered in some detail. F's reactions are omitted; the fixed points are underlined:

A, Am beste is. Sie gehn jetzt auf die anner Seit: un hinner der Kirch überqueren Sie die Straß, ja? Dann gehn Se an de Kaiserstraß e Stück erunter, bis Se an de nächst Ampel komme; da gehn Se links erein un dann sind Se gleich dort: da links, gell, da links erein. e Stück, un $d a$ geht links e Straß un rechts; die rechte Straß, das is der Große Hirschgraben; da kommt gleich 's Goethehaus.

[ You best go to the other side now: and behind the church, you cross the street, okay? There you go a bit down the Kaiserstraße, till you get to the next light; there you turn left and then you are almost there; there to the left, all right, there to the left, a bit. and there to the left and to the right is a cross street; the street on the right, that's the Große Hirschgraben; shortly after that is the Goethehaus.]

'Die anner Seit' ( = the other side) is a type 4 expression, combined-as often happens-with non-deictic information; it refers back to the original location: 
that side which is not here. ${ }^{8}$ The next fixed point 'hinter der Kirch' (= behind the church) is visual with a deictic component: 'behind'. What is meant is 'behind the church that is before our eyes'. The next one is 'die Straß' (= Katharinenpfad); it is again a type 4 expression: 'die Straß' here means: that street that you will reach if you go on behind the church. The next fixed point, 'an de Kaiserstraß", has a peculiarity: an expression may be used this way only if the denotatum can be assumed to be known to the listener, i.e. the way in which the fixed point is introduced corresponds to type 1. But A can't assume that $\mathrm{F}$ knows the Kaiserstraße; either he assumes it nevertheless, or he assumes that $\mathrm{F}$ is able to read a street sign, i.e. that he is able to acquire the necessary knowledge. There follows again a fixed point of type 4. 'die nächst Ampel". The next point, 'dort', is clearly deictic, but it doesn't fit the general pattern: it is the first marking of the final destination; it means 'there, where you want to go', rather than 'at the traffic lights'. (Incidentally, this is one of the rare cases where the strictly serial order of the fixed points is given up.) The lights are taken up by the deictic expression 'da links, gell, da erein". which, however, doesn't introduce a new fixed point. Again, this is done by an expression of type 3: that place, where there is a street to the left and a street to the right. This expression also contains a deictic component, and it could be argued that it is a combination of types 3 and 4 . With its aid. the next and-apart from the destination itself-last fixed point is introduced: 'der große Hirschgraben'. All that remains is the final marking.

Such a series of fixed points, together with some additional information perhaps, forms a rudimentary picture of a deictic space; the picture is completed if the imaginary traveller becomes a real one, and it is sufficient to set up-by means of local deictics-a lot of localities where certain actions are to be performed..$^{9}$ This is done by the deictics 'hier', 'da', and 'dort'. 'Here' is usually used to refer to a space around the initial location whose borders are not specified-because there is no need to do so. The denotatum of 'dort' and 'da' (in local sense) is not the fixed point with which it is used: 'bis Se an de nächst Ampel komme; da gehn Se links rein'. 'Da' refers to the space around the imaginary position of the speaker at the fixed point in question. No delimitation is used; it is expected that $\mathrm{F}$ will draw the borders from his factual knowledge.

How this mechanism works is perhaps more clearly to be seen with the deictics 'left' and 'right', whose denotatum not only depends on the-real or imaginary-position of the speaker, but also on his-real or imaginarydirection of gaze. There is one case in the data where the same street, the Biebergasse or its continuation, the Freßgasse. is described in relation to the same fixed point one time as to the left $(\mathrm{Ol})$.

A Hier vor bis zum Kaufhof [...] und da halten Sie sich rechts, geradeaus durch die Freßgasse 
the other time as to the right (C)4).

A Jetzt gehen Sie vor, bis ganz vorn hin, bis an den Kaufhof stoßen, dann gehen Sie links rein, die Biebergasse

This is simply due to differences of position and their consequences. In $\mathrm{O} 1$, the original position is in the Zeil (see Figure 1); speaker and listener gaze in the direction of the Hauptwache. If $\mathrm{F}$ is thought to move in this direction and if-and this seems most natural-he maintains his direction of gaze, the Freßgasse (or the Biebergasse) will be to his right, as soon as he arrives at the fixed point 'Kaufhof'. In 04 . the original position is south-east of the Hauptwache: speaker and listener gaze towards the Kaufhof, and at this fixed point, the Kaufhof. the Biebergasse is to the left. What 'left' and 'right'-and analogously 'dort', 'da', 'hier'-mean is determined by the origo and by the direction of gaze. In route directions, both position and direction underly a constant imaginary change. In this case, the determinants of local deixis are set up by the explicitly fixed points, on the one hand, and by the normal and expected course of events - of walking and looking in an imaginary space.

\section{NOTES}

1. I wish to thank V. Ehrich. R. Jarvella. A. Kratzer. W. Levelt. M. Miller, E. Schegloff. M. Silverstein. J. Weissenborn. and D. Wunderlich for helpful comments and criticisms on earlier versions. Special thanks go to Elena Lieven. who has made numerous stylistic corrections: if my English is understandable, it is mainly to her merit.

2. This study is described in greater detail in Klein (1979). It not only concerns the use of deictics. but also interactive and cognitive aspects of the complex verbal action of asking for the way and giving route directions.

3. I don't see any substantial difference between deictic and anaphoric use of 'here' (and. in a similar way. of 'he', 'that', etc.) Anaphorical (and in the same way cataphorical) use is just that special case of deictic reference where the reference unit is verbally introduced into the context, whereas in other cases it is there by gestures, by shared perception, or by shared knowledge.

4. This may lead to some confusion with people who professionally take over the listener's orientation, such as opticians and ophthalmologists. The usual method of co-ordinating perspectives then leads to wrong results. On the other hand, it seems that in imperatives, it is generally the listener's perspective that is decisive: 'turn right!' always means 'tum right from your perspective!' This is true at least in route directions.

5. It is precisely this idea that makes the assumption of deictic spaces being provided with a topological structure so tempting. Where a structure defined, the possible denotata could be identified with the neighbourhoods or rather a subset of the neighbourhoods If it is some distinguished element of the topological space, the possible denotata of 'here' could be a subset of all those neighbourhoods that contain $x$ as an element. But suggestive as this idea may be-it does not give us the topology 
6. This is somewhat simplified, since 'there' cannot be applied to places with objects which the speaker is touching. I cannot say 'the book there' when touching it. Touching turns everying into here.

7. The expressions used in the route directions may be subdivided into three classes, according to their function: descriptive expressions, commenting expressions. and interactive expressions. The speaker may comment upon what he says, or on the difficulty of the task or route; typical are expressions like 'oh, that's quite near', 'well, it's complicated', etc With interactive expressions. A checks whether F got the message or simply whether $\mathrm{F}$ is still following his explanations, and $\mathrm{F}$ signals that he is still receiving' and that A can and should continue; a standard technique is ' $\mathrm{mhm}$ ' with question intonation on $\mathrm{A}$ 's side and with affirmative intonation on F's side (for some details see Klein. 1979. pp. 33-37).

8. It is precisely the deictic character of the word 'other' that is used in the famous riddle about the village of liars, the village of truth-tellers, and the cross-roads where somebody from one of the villages-it is not known which one-is sitting. If one has to discover using only one yes/no question whether the village of the truth-tellers is to the left or to the right, one must ask: 'Would somebody from the other village send me left for the village of the truth-tellers'. The reference of 'somebody from the other village' is different depending on the person sitting there.

9. A similar result can be obtained by using temporal deictics; they are determined by the sequence of actions: 'dann' means 'at the moment after you have done what 1 previously said'. I don't consider these uses here.

\section{REFERENCES}

Atkinson. M.. \& Griffiths, P. D. (1973). Here's here's, there's, here and there. Edinburgh Working Papers in Linguistics 3 (mimeo).

Bühler. K. (1934). Sprachtheorie. Jena: Fischer.

Clark. E. (1977) From gesture to word: on the natural history of deixis in language acquisition. In J. S. Bruner \& A Garton (eds). Human growth and development Wolfson College lectures. 1976 Oxford: Oxford University Press

Davis. P W., \& Saunders. R. (1975). Bella Coola nominal deixis Language. 51. $845-858$.

Downs. R . \& Stea. D. (eds) (1973) Image and environment. Chicago: Aldine.

Downs. R . \& Stea. D. (1977) Maps in minds. New York: Harper \& Row.

Fillmore. C. (1975) Santa Cruz lectures on deixis. 1971. Bloomington. Ind : Indiana University linguistics Club

Klein. W. (1979). Wegauskünfte Zeitschrift für Literaturwissenschaft und Linguistik. 33. $9-57$.

Klein. W., \& Levelt. W. J. M. (1978). Sprache und Kontext Die Naturwissenschaften. 65. 328-335.

Kratzer. A.. \& von Stechow. A (1976) Äußerungen und Bedeutung Zeitschrift für Literaturwissenschaft und Linguistik. 23/24. 97-130

Labov. W . \& Linde. C (1975) Spatial networks as a site for the study of language and thought Language. 51. 924-939

Lynch. K (1960) The image of a city Cambridge. Mass.: MIT Press.

Miller. G A . \& Johnson-Laird. P N (1976) Language and perception Cambridge.

Mass : Harvard University Press

Wunderlich. D (1976) Studien zur Sprechakttheorie, Frankfurt/Main: Suhrkamp 


\section{APPENDIX: SELECTED TRANSCRIPTIONS}

02

F Zum alten Opernhaus

To the old Opera House

A Ja?

Yes?

F ja

$$
\text { yes }
$$

jaaa [ 10 seconds] da gehen Sie jetzt bis yahhh you go now as far as oben drüber, ja above there, yes

A zur Zeil oben drüber, nicht unten durch

the Zeil above there, not below

$\mathrm{F}$

A oben drüber, gehen durch die Goethestraße durch, und dann kommen above there, you go through the Goethestraße, and shortly you dankeschön thank you

A Sie direkt an die alte Oper bitte. Wiedersehen will be at the old Opera you're welcome, see you.

017

F Entschuldigen Sie. können Sie mir sagen, wie man zur alter Oper kommt? Excuse me, could you tell me how to get to the old Opera?

A

$\mathrm{F}$

A na. oh ja doch [ 2 seconds] Sic können [2 seconds] hier rauf [2 seconds] bis well, oh ves, you can here that way till $\mathrm{F}$ jaha yah uhhuh

A $[6$ seconds] ehm. ich muß auch erst überlegen weil's von bissei ehm. let me think first myself

$\mathrm{F}$ 'cause it's been
A verbaut wurde: [4 seconds] Sie gehen jetzt hier eh zur Ecke dann
A verbaut wurde: [4 seconds] Sie gehen jetzt hier eh zur Ecke dann $\mathrm{F}$ changed a bit here now YOU go here to the corner then ja yes

A links oben über den Platz, dann gehn Sie geradeaus, das ist die $\mathrm{F}$ to the left up above across the square, then straight on. that's the ja 
A Goethestraße, also nicht diese, sondern die nächste dann rauf, und dann Goethestraße, that is not this one but the next one, up it then, and then $\mathrm{F}$ $\mathrm{mhm}$ $m h m$

A stoßen Sie direkt das ist dann auf der rechten Seite ist dann die you run immediately into that is on the right side then is the

F $\quad \mathrm{mhm}$ $m h m$ gutt. dankeschön okay, thank you

A alte Oper das sehen Sie schon; old Opera you'll see it then bitte you're welcome.

G2

Können Sie mir sagen, wie man zum Goethehaus kommt? Could you tell me how to get to the Goethe House?

Goethehaus?

Goethe House?

nee. Großer Hirschgraben war das. glaub ich no. it was Großer Hirschgraben. I think

keine Adresse?

bitte?

no address? sorry?

Großer Hirschgraben, die Straße [5 seconds] Wissen Se nicht. Großer Hirschgraben, the street You don't know, fragen wir nochmal. we'll ask somebody else.

G4

Können Sie mir sagen, wie man zum Goethehaus kommt? Zum Could VOM tell us how to get to the Goethe House?

Goethehaus

Goethe House
Goethe

Goethe
Güterhaus?

Goods House? $\mathrm{hm}$. das ist hier etwa. Goethe, hm. that's here somewhere, Goethe,

Goethe. Goetheplatz. Goetheplatz und Goethehaus. he.

Goethe. Goethe place. Goethe Place and Goethe House, hey, ja. ja. ja. oh yes, sure, 
ich glaube da is da. oder? ganz in der Nähe davon

I think it's there, or? around here somewhere

$\mathrm{F}$

A wenn Sie hierher, also wenn Sie jetzt über die Straße gehen.

if you here. well, if you cross the street now,

$\mathrm{F}$

A ja und dann gehn Sie gerade, ich glaube da wo ist die Kirche okay. and then go straight on. I think there where is the church ja. danke yes, thanks
bitte.
A da muß sie[!] irgendwo sein there she must he somewhere
vou're welcome.

okay. okay.

\section{G17}

F Entschuldigung, können Sie mir sagen, wie man hier zum Excuse me. could you tell me how to get to the

A

F Goethehaus kommt?

Goethe House here?
A
ja: Moment yes. just a moment
$\mathrm{F}$
A du mußt hier durch, ja?
you have to go through here, alright?
$\mathrm{F}$
ja
yes
und [4 seconds]okay.
and okay.

A wie am besten, ja: hier durch, ja? is auch eine Straße: sehn Sic what's the best, yes; through here, okay? there is another street: do you see ja. ja yes, sure
A dieses Schild Bill-Binding Bier da oben, ja? okay, und dann da this sign Bill-Binding Beer up there, yeh?
$\mathrm{F}$ $\mathrm{mhm}$ $m h m$
A geradeaus und jetzt is es entweder, es gibt eh zwei kleine Gasse. straight on and now it's either, there are er two small side streets,


A ja, eh immer geradeaus, und dann kurz vor Berliner Straße, yes, ah, you keep going straight, and then shortly before the Berliner Straße,

F

A eh eh, irgendwo in dieser Richtung, das weiß ich auch nicht so weit ah ah, somewhere in that direction; I'm not quite sure, either so far

$\mathrm{F}$ is gut. danke that's fine, thanks

fünf Minuten, ja? auf der rechten Seite

A in five minutes, okay? on the right side,

$\mathrm{F}$ ja, is gut. vielen Dank yes, that's fine, thanks a lot

A eh aber zuerst hier runter but first down here okay okay. 